Article

\title{
Antibacterial Activity of 7-Epiclusianone and Its Novel Copper Metal Complex on Streptococcus spp. Isolated from Bovine Mastitis and Their Cytotoxicity in MAC-T Cells
}

\author{
Mariana de Barros ${ }^{1}$, Pedro Griffo Perciano ${ }^{\dagger}$, Marcelo Henrique dos Santos ${ }^{2}$, \\ Leandro Licursi De Oliveira ${ }^{3}$, Éderson $D^{\prime}$ Martin Costa ${ }^{4}$ and \\ Maria Aparecida Scatamburlo Moreira 1,* \\ 1 Department of Veterinary, Universidade Federal de Viçosa, Viçosa 36570-900, Brazil; mariana.barros@ufv.br \\ 2 Department of Chemistry, Universidade Federal de Viçosa, Viçosa 36570-900, Brazil; \\ marcelo_hs@yahoo.com.br \\ 3 Department of General Biology, Universidade Federal de Viçosa, Viçosa 36570-900, Brazil; \\ leandro.licursi@ufv.br \\ 4 Institute of Chemistry, Universidade Federal de Alfenas, Alfenas 37130-000, Brazil; \\ edm_quimica@yahoo.com.br \\ * Correspondence: masm@ufv.br; Tel.: +55-31-3899-1471 \\ + Deceased.
}

Academic Editor: Kelly Chibale

Received: 23 March 2017; Accepted: 10 May 2017; Published: 17 May 2017

\begin{abstract}
Mastitis is an inflammation of mammary gland parenchyma that adversely affects bovine health and dairy production worldwide despite significant efforts to eradicate it. The aim of this work was to characterize the antimicrobial activity of 7-epiclusianone (7-epi), a compound extracted from the Rheedia brasiliensis fruit, its complex with copper against Streptococcus spp. isolated from bovine mastitis, and to assess their cytotoxicity to bovine mammary alveolar cells (MAC-T). The complex 7-epiclusianone- $\mathrm{Cu}$ (7-epi-Cu) was an amorphous green solid with optical activity. Its vibrational spectrum in the infrared region showed absorption bands in the high-frequency region, as well as bands that can be attributed to the unconjugated and conjugated stretching of the free ligand. The complex was anhydrous. One of the tested bacterial strains was not sensitive to the compounds, while the other three had MIC values of $7.8 \mu \mathrm{g} \mathrm{mL}^{-1}$ and minimum bactericidal concentration (MBC) values between 15.6 and $31.3 \mu \mathrm{g} \mathrm{mL} \mathrm{m}^{-1}$. These two compounds are bacteriostatic, did not cause damage to the cell wall and, at sub-inhibitory concentrations, did not induce bacterial adhesion. The compounds were not cytotoxic. Based on these results, 7-epi and 7-epi-Cu exhibited desirable antimicrobial properties and could potentially be used in bovine mastitis treatment.
\end{abstract}

Keywords: 7-epiclusianone; mastitis; bacterial activity; cytotoxicity; MAC-T; Streptococcus spp.; Rheedia brasiliensis

\section{Introduction}

The human species has always used plants to control and eradicate diseases [1]. According to the World Health Organization, 70-80\% of the world's population depends exclusively on herbs for their primary health care [2]. Compounds isolated from plants are currently applied in modern therapies and play an important role in the synthesis of more complex molecules [3]. In this context, natural products have become an important source for the discovery of new therapeutic agents. Plants are especially rich in these types of compounds due to their wide chemical diversity [4] and represent an important source for new varieties of molecules [2]. 
Plants from the genus Rheedia are often used in Brazilian folk medicine to treat disorders, such as constipation, rheumatism, inflammation, and pain [5]. Rheedia brasiliensis is native to the Amazonian region, planted all across Brazil, and popularly known as bacupari [6]. From its fruit, the molecule 7-epiclusianone (7-epi) was extracted (Figure 1) and shown to have a broad spectrum of biological activities [4] including toxicity to Trypanosoma cruzi trypomastigotes [7], vasodilation [8], anti-anaphylaxis [9], anti-HIV [10], antinociception, and anti-inflammation [11], among others. Vieira and colleagues [12] have investigated this compound using two epithelial cell lines: normal MDCK from canine kidneys and IIN-5 from a human carcinoma of the tongue. Their results clearly demonstrate that cellular reproduction time was reduced in the presence of 7-epi.

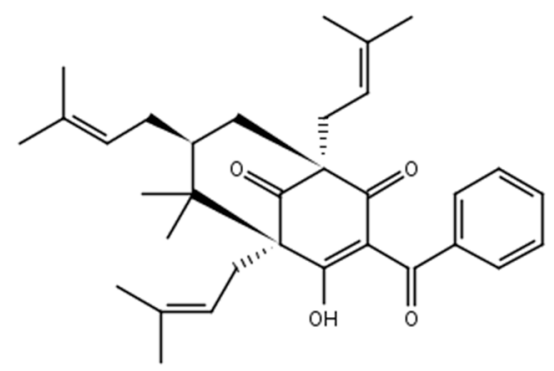

Figure 1. Chemical structure of 7-epiclusianone.

Compounds obtained from natural sources can be modified to make them more effective or less toxic [2]. A good strategy to increase antimicrobial activity is to complex active molecules with metals [13]. The antimicrobial properties of silver, copper, gold, titanium, and zinc all have distinct properties, potency, and activity that have been known and applied for centuries [14]. Traditional treatments utilize metallic ions with natural compounds. Historically, Chinese and Arabs used zinc to promote wound healing, while Egyptians used copper to sterilize water [15]. There is growing interest in $\mathrm{Cu}^{2+}$ complexes [16]. Among metallic ions, copper and its compounds have been used as effective agents against bacteria, fungi, viruses, and mollusks. Copper is a cheap metal and it is readily available, which makes it attractive for synthesis of new molecules [17]. There is a concern regarding the use of copper due to it toxicity, which occurs as an imbalance between influx and excretion resulting in liver cell damage [18]. Ruminants generally do not control copper uptake, storage, and biliary secretion, but cattle and goats can be considered copper-tolerant species [19].

Mastitis is an inflammation of mammary gland parenchyma that adversely affects bovine health and dairy production worldwide [20]. It is a complex disease with many factors [21]. This disease causes large financial losses in the milk production chain due to lesions on the secretory epithelial cells of mammary glands, which decrease milk production and excretion [22] The presence of pathogens in raw, unpasteurized milk increases the risk of their ingestion and transmission, as well as the potential ingestion of dangerous toxins [21,23]. There are literature reports of microorganisms that survive high pasteurization temperatures. [24]. Another public health concern is the extensive use of antimicrobials for mastitis treatment. This type of control has possible implications for human health by increasing the risk that resistant strains could enter the food chain or cause allergic reactions [21].

Streptococcus species, including Streptococcus agalactiae and Streptococcus uberis, are among the main mastitis pathogens [25]. Despite intense research and multiple approaches implemented over the past decades, bovine mastitis persists in milk herds [21]. Mastitis prevention and treatment comprise the majority of antimicrobial use in dairy cattle, resulting in substantial costs to the industry [26] and necessitating the search for new treatments. Additionally, unsuccessful treatment has prompted research into new approaches in order to reduce antimicrobial use [27].

The aim of this work was to characterize 7-epi and its metal complex 7-epiclusianone-copper (7-epi-Cu) and verify their antimicrobial activity on Streptococcus spp. isolated from bovine mastitis and assess their cytotoxicity in bovine mammary alveolar cells (MAC-T). 


\section{Results and Discussion}

\subsection{Chemistry}

The compound 7-epi-Cu (Figure 2) was characterized by elemental analysis (CHN), atomic absorption, thermal analysis (TG), infrared (IR), nuclear magnetic resonance (NMR), ultraviolet/visible (UV-VIS) spectroscopy, and optical activity $\left([\alpha]_{\mathrm{D}}\right)$.

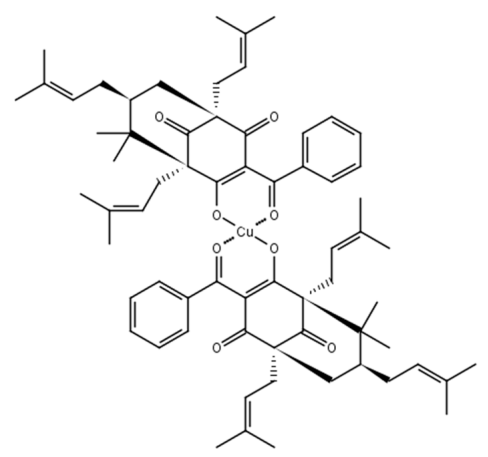

Figure 2. Chemical structure of the complex of 7-epiclusianone and $\mathrm{Cu}^{2+}$ (7-epi-Cu).

The 7-epi-Cu complex was an amorphous green solid with an optical activity $[\alpha]_{\mathrm{D}}^{25}=-70.1^{\circ}$ (c 1.00, $\mathrm{CHCl}_{3}$ ). The results were consistent with a stoichiometry containing two 7-epi ligands for each metal center (1:2) $\left(\mathrm{Cu}^{2+}\right.$ : 7-epi) and $\mathrm{C}_{66} \mathrm{H}_{82} \mathrm{CuO}_{8}$ : theoretical, $\mathrm{C}(74.30 \%), \mathrm{H}(7.75 \%), \mathrm{Cu}(5.96 \%)$; experimental, C (75.66\%), H (7.60\%), Cu (6.19\%), which corresponded to a molar mass of 1065 Daltons.

The vibrational IR spectrum (Figure 3) of 7-epi-Cu showed absorption bands in the high-frequency region of the spectrum at $2966 \mathrm{~cm}^{-1}$ and $2913 \mathrm{~cm}^{-1}$, which we attributed to the aliphatic $v_{(\mathrm{C}-\mathrm{H})}$ stretching of the methyl groups, as well as bands at $3062 \mathrm{~cm}^{-1}$ corresponding to aromatic $v_{(\mathrm{C}-\mathrm{H})}$ from the binder. The absorption bands attributed to the unconjugated $\left(1725 \mathrm{~cm}^{-1}\right)$ and conjugated $\left(1667 \mathrm{~cm}^{-1}\right)$ stretching of the free ligand were displaced in the complex. The adsorption of the $v_{(C=O)}$ conjugate at $1667 \mathrm{~cm}^{-1}$ in the free ligand appeared to be displaced due to the small number of complexes $\left(1656 \mathrm{~cm}^{-1}\right)$ corresponding to the coordination of the oxygen atom to $\mathrm{Cu}^{2+}$. In addition, the $1583 \mathrm{~cm}^{-1}$ band that we attributed to the $v_{(\mathrm{C}=\mathrm{C})}$ stretch of the aromatic ring of the 7-epi ligand was also observed in the complex with a band at $1533 \mathrm{~cm}^{-1}$. In fact, the band corresponding to the $v_{(\mathrm{O}-\mathrm{H})}$ stretch of the free 7-epi ligand was not observed in the spectrum of the complex due to deprotonation of the ligand.

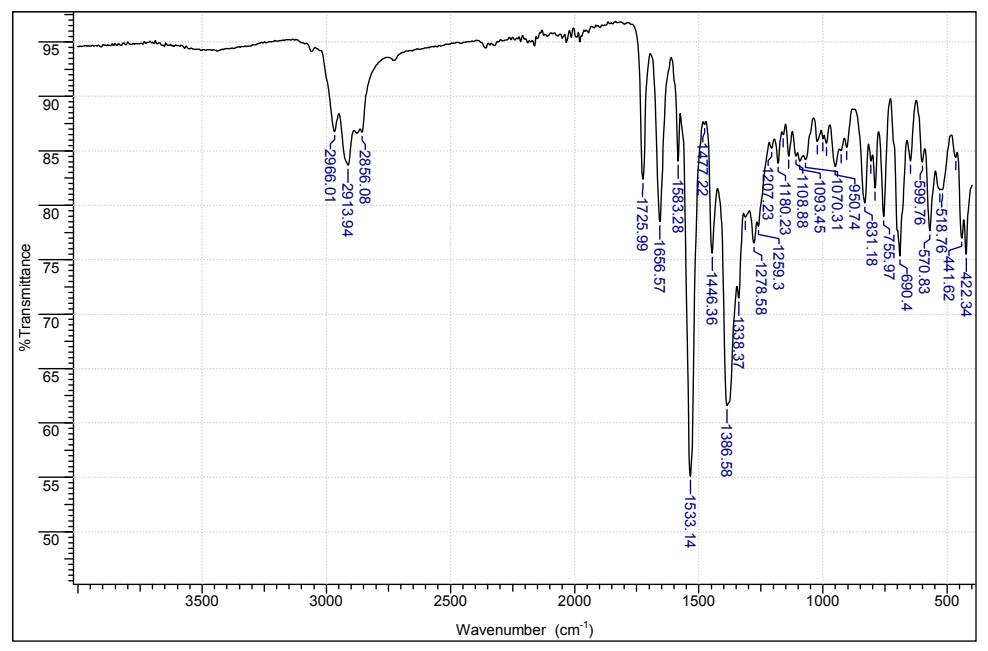

Figure 3. Infrared spectrum (IR) of 7-epiclusianone-copper (liquid film). 
In the UV-VIS spectra (Figure 4) note a bathochromic shift in the complex (7-epi-Cu) when compared with the ligand (7-epi) in addition to a new band at $667 \mathrm{~nm}$ relative to the green color absorption showing that the complexation modified the chromosphere group in the ligand [6].

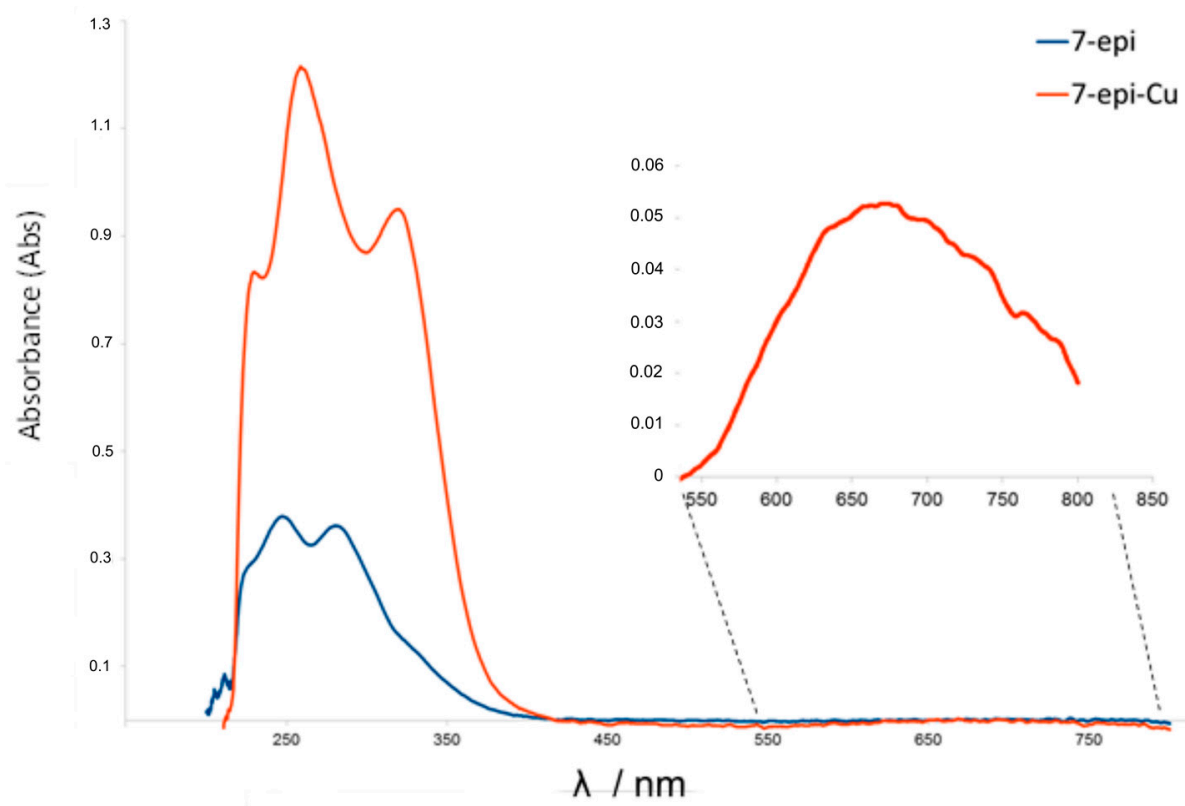

Figure 4. UV-VIS spectra of 7-epi (blue) and 7-epi-Cu (red) $\left(0.04 \mathrm{mmol} \mathrm{L}^{-1}\right.$ in methanol) showing the green color absorption of the 7-epi-Cu at $667 \mathrm{~nm}$ in the magnified region.

Comparative analyses of the ${ }^{1} \mathrm{H}-\mathrm{NMR}$ spectra (Figure 5) of 7-epi-Cu with 7-epi [6] were used to identify the signals corresponding to $8 \mathrm{CH}_{3}(\delta 0.6-1.6), 4-\mathrm{CH}_{2}(\delta 1.5-3.3), 1-\mathrm{CH}(\delta 1.0), 3 \mathrm{C}=\mathrm{C}-\mathrm{H}$ $(\delta 4.5-5.5), 5 \mathrm{C}=\mathrm{C}-\mathrm{H}_{\text {aromatic }}(\delta 6.5-7.6)$ aromatic hydrogen and groups. The signals show a similar feature of paramagnetic spectra with distorted divide in the presence of $\mathrm{Cu}^{2+}$.

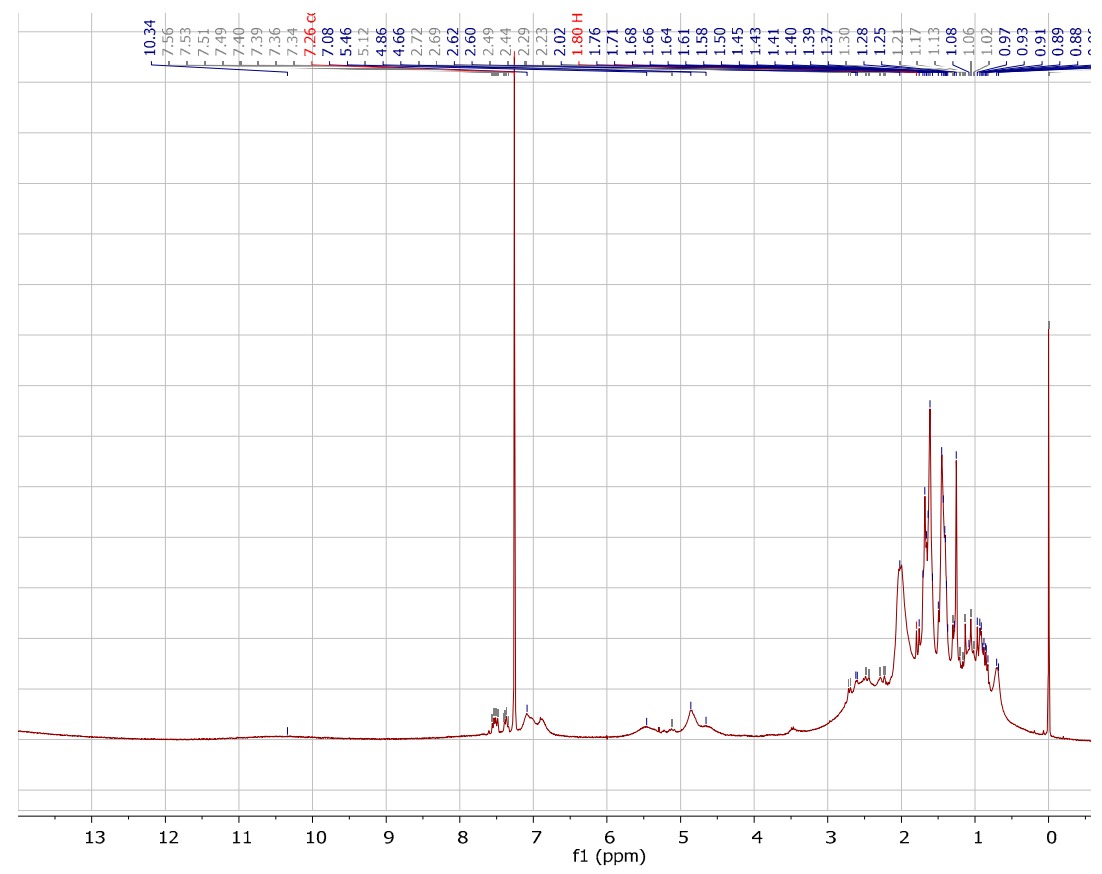

Figure 5. ${ }^{1} \mathrm{H}-\mathrm{NMR}$ spectrum of 7-epi-Cu (300 MHz, $\left.\mathrm{CDCl}_{3}\right)$. 
Comparative analyses of the ${ }^{13} \mathrm{C}-\mathrm{NMR}$ spectra (Figure 6) of 7-epi-Cu with 7-epi [6] were used to identify the signals corresponding to quaternary $\left(8 \mathrm{sp}^{2}\right.$ and $\left.2 \mathrm{sp}^{3}\right)$, methine $\left(9 \mathrm{sp}^{2}\right.$ corresponding to $7 \mathrm{sp}^{2}$ and $2 \mathrm{sp}^{3}$ ), methylene $\left(3 \mathrm{sp}^{3}\right)$, and methyl (six attached to $4 \mathrm{sp}^{2}$ and two bonded to $\mathrm{sp}^{3}$ ) carbon atoms. Relative to carbonyl groups, were observed at $\delta 208.1$ the non-conjugated carbonyl, and at $\delta 197.5,196.7$, and 193.6 the system conjugated carbonyl responsible for the complexation with the metal. The other signals were also similar to 7-epi [6].

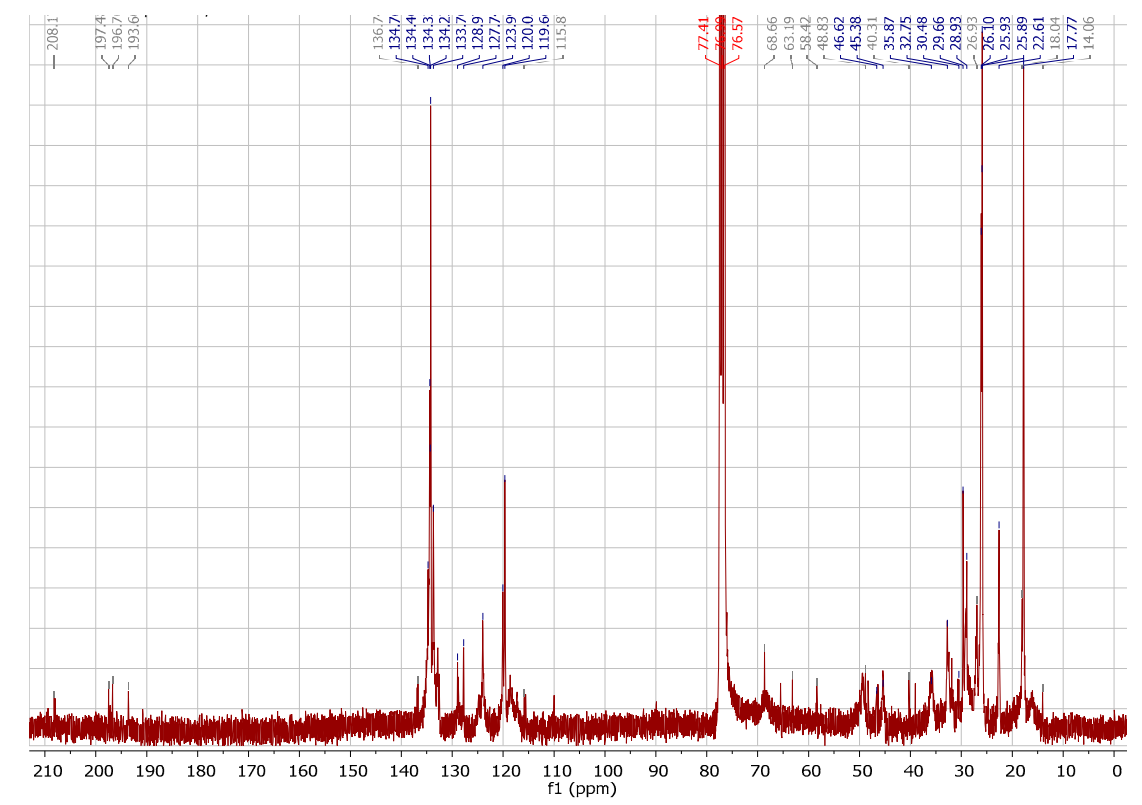

Figure 6. ${ }^{13} \mathrm{C}-\mathrm{NMR}$ spectrum of 7-epi-Cu $\left(75 \mathrm{MHz}, \mathrm{CDCl}_{3}\right)$.

TG was performed in a nitrogen atmosphere. The thermogravimetric curve shows that the complex was anhydrous, due to the existence of a plateau in stability up to $300^{\circ} \mathrm{C}$ (Figure 7). Above this temperature, thermodecomposition of the complex began, with a visible loss in mass of $91.64 \%$ at $500{ }^{\circ} \mathrm{C}$, which was consistent with the decomposition of the 7-epi ligands (calc. 93.92\%). The observed 8.36\% residue was tentatively attributed to $\mathrm{CuO}(7.45 \%)$.

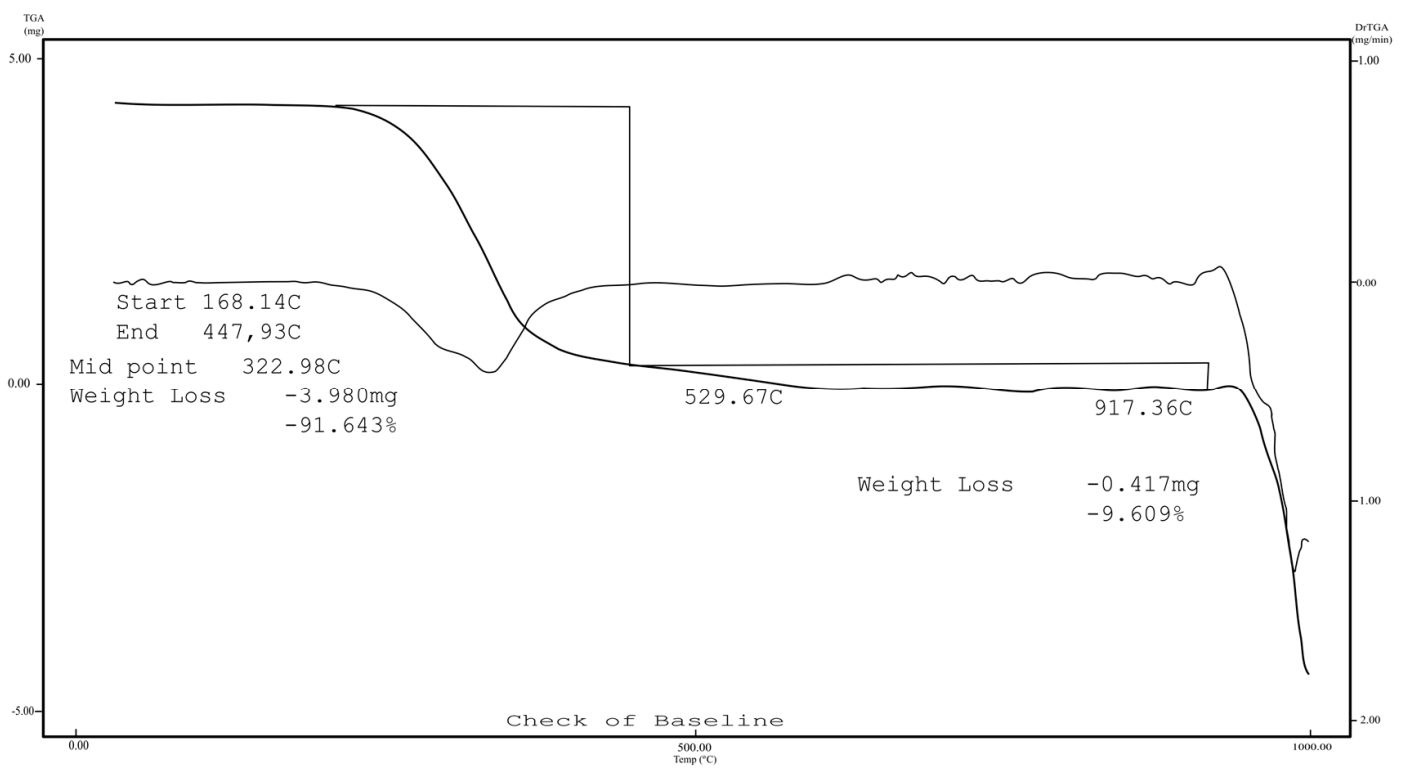

Figure 7. Thermal analysis (TG) curves of 7-epiclusianone-Cu. 


\subsection{Minimum Inhibitory Concentration (MIC) and Minimum Bactericidal Concentration (MBC)}

Strains SA4038, SU959, and SU3580 had MICs of $7.8 \mu \mathrm{g} \mathrm{mL}^{-1}$ for both molecules. Strain SA3930 was resistant to them (Table 1).

Table 1. Minimum inhibitory concentration (MIC) and minimum bactericidal concentration (MBC) values for Streptococcus agalactiae (SA) and Streptococcus uberis (SU) isolated from bovine mastitis related by 7-epiclusianone (7-epi) and 7-epiclusianone-copper (7-epi-Cu).

\begin{tabular}{lcccc}
\hline \multirow{2}{*}{ Strains } & \multicolumn{2}{c}{ MIC } & \multicolumn{2}{c}{ MBC } \\
\cline { 2 - 5 } & \multicolumn{3}{c}{ Compounds $\left(\mu \mathrm{g} \mathrm{mL} \mathbf{~}^{-1} / \mu \mathbf{M}\right)$} \\
\cline { 2 - 5 } & 7-epi & 7-epi-Cu & 7-epi & 7-epi-Cu \\
\hline SA3930 & - & - & - & - \\
SA4038 & $7.8 / 15.5$ & $7.8 / 7.3$ & $15.6 / 31.1$ & $31.3 / 29.3$ \\
SU959 & $7.8 / 15.5$ & $7.8 / 7.3$ & $31.3 / 62.2$ & $31.3 / 29.3$ \\
SU3580 & $7.8 / 15.5$ & $7.8 / 7.3$ & $31.3 / 62.2$ & $31.3 / 29.3$ \\
\hline
\end{tabular}

According to Ríos e Recio [28], inhibitory activity values below $10 \mu \mathrm{g} \mathrm{mL}^{-1}$ for plant compounds are considered relevant. Cos et al. [29], in turn, described significant inhibitory activity as below $25 \mu \mathrm{g} \mathrm{mL}^{-1}$. Thus, based on these reports, 7-epi and 7-epi-Cu were significantly inhibitory (Table 1). The strain SA3930 was not used in the MBC assay since it showed no sensitivity to the tested compounds in the MIC test.

Metals have several mechanisms by which they induce microbial toxicity including protein dysfunction, production of reactive oxygen species and the depletion of antioxidants, disruption of membrane function, interference with nutrient assimilation, and genotoxicity [30]. Copper ions have been reported to be effective against bacteria and fungi isolated from mastitis [31], and its activity was expected to increase in a complex.

Comparing the activity of sulfathiazole and nimesulide complexed with or without copper, complexes with copper exhibited superior results and had activity, while copper alone was not active [15]. Santi et al. [13] evaluated the biological activity of free xylitol and xylitol complexed with copper or zinc and found that the MIC value for the complex was half that of free xylitol. In our study we found the same MIC value for 7-epi and its complex with copper, $7.8 \mu \mathrm{g} \mathrm{mL} \mathrm{m}^{-1}$.

Micro-organisms have genetic and biochemical mechanisms to combat metal toxicity, such as reduced absorption, efflux, extracellular sequestration, intracellular sequestration, repair, contouring pathways, and chemical modification [30]. Some of these mechanisms may explain the similarity in the antibacterial activity exhibited by benzophenone 7-epi and its complex with copper.

Another possibility for the similar activity values of 7-epi and 7-epi-Cu could be the existence of steric hindrance, which means that, in the spatial conformation of the molecule, the copper ion may not be accessible and is, therefore, unable to exert any antimicrobial activity. Furthermore, the size of the complex (1065 $\mathrm{g} \mathrm{mol}^{-1}$ ) may prevent its action.

\subsection{Time-Kill Curve}

A time-kill curve provides concentration-time profiles that can be used in addition to in vivo studies to improve dosage planning [32].

The dynamics of the time-kill curves for S. agalactiae and S. uberis treated with 7-epi and 7-epi-Cu revealed that these two compounds act by inhibiting proliferation of these bacteria and are, thus, bacteriostatic. This behavior was also observed in the CBM, which was a higher concentration than the MIC (Figures 8 and 9). 


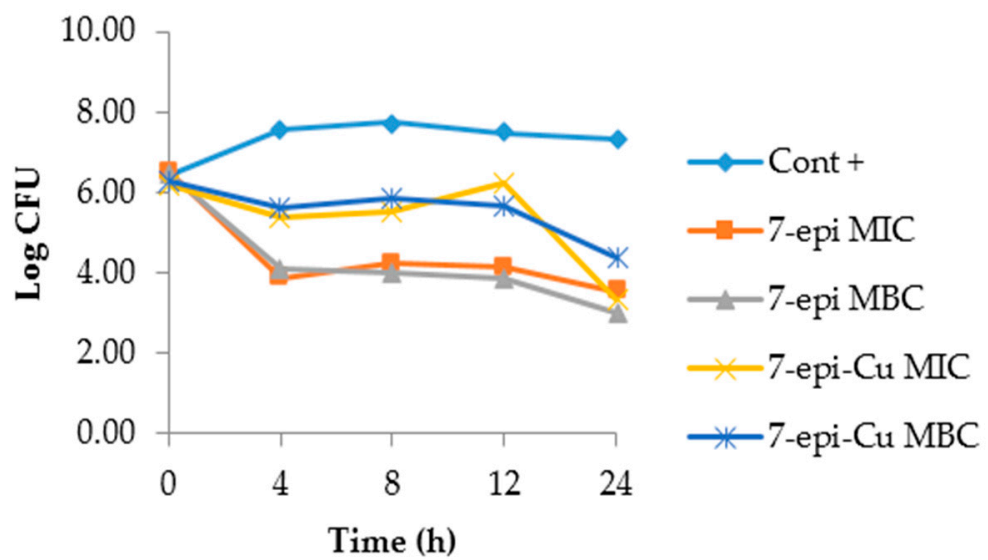

Figure 8. Time-kill curve of Streptococcus agalactiae isolated from mastitis after treatment with 7-epiclusianone (7-epi) and 7-epiclusianone- $\mathrm{Cu}(7$-epi- $\mathrm{Cu})$ at the minimal inhibitory concentrations $\left(\mathrm{MIC}=7.8 \mu \mathrm{g} \mathrm{mL}^{-1}\right)$ and minimal bactericidal $\left(\mathrm{MBC}=15.6\right.$ and $31.3 \mu \mathrm{g} \mathrm{mL}^{-1}$ for 7-epi and 7-epi-Cu, respectively). Cont $+=$ Growth curve for $S$. agalactiae .

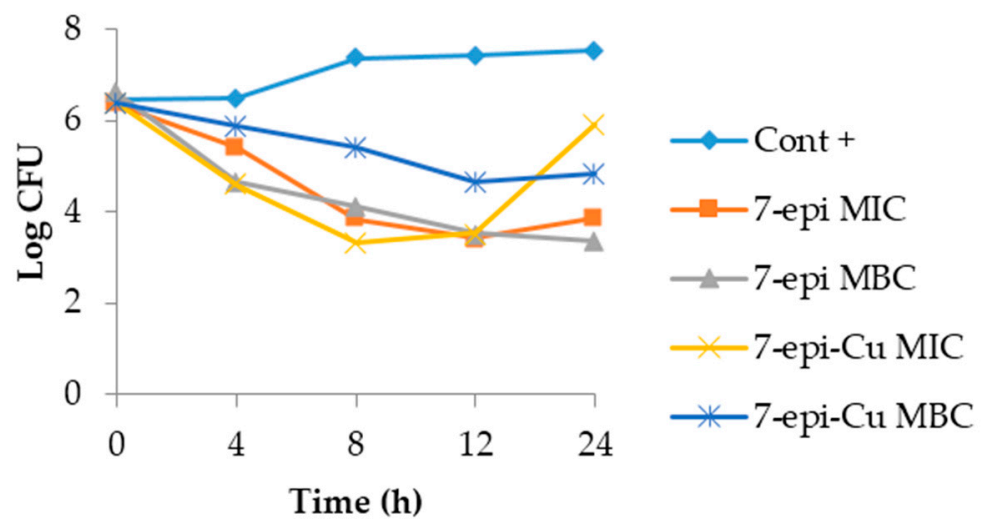

Figure 9. Time-kill curve of Streptococcus uberis isolated from mastitis after treatment with 7-epiclusianone (7-epi) and 7-epiclusianone- $\mathrm{Cu}(7$-epi- $\mathrm{Cu})$ at the minimal inhibitory concentrations $\left(\mathrm{MIC}=7.8 \mu \mathrm{g} \mathrm{mL}^{-1}\right)$ and minimal bactericidal $\left(\mathrm{MBC}=31.3 \mu \mathrm{g} \mathrm{mL}^{-1}\right)$. Cont + is the growth curve for S. uberis.

The 7-epi compound and its complex with copper had the same pattern during the observation period where bacterial growth was inhibited. The behavior was similar for the two concentrations tested. This result demonstrates that the behavior of 7-epi and 7-epi-Cu are not time/dose-dependent. Pankey and Sabath [33] described reports of the most important clinical results for drugs with bactericidal activity relative to bacteriostatic agents and found that in vitro results are not sufficient to predict in vivo behavior. Furthermore, drug action is dependent upon the bacterial concentration and interaction with the immune system at the site of infection [34], thus, the bacteriostatic behavior of 7-epi and 7-epi-Cu against these two bacterial species is not a negative feature.

A theoretical complication of using bacteriostatic agents would be a relapse after infection treatment as the infectious agent is not totally eliminated. Nemeth et al. [34] looked for clinically -relevant distinctions between bactericidal and bacteriostatic antimicrobials and found no difference in the infection recurrence rate between these two categories.

Bactericidal compounds may lead to toxin release and the release of cell wall fragments, which leads to the increased release of prostaglandins and results in an exaggerated inflammatory response [33]. 


\subsection{Protein Leakage Assay}

The presence of protein in the supernatant is indicative of a disruption in the integrity of the bacterial cell wall [35]. There was no statistical difference in the amount of protein in the supernatant between treatments and controls at any of the studied time points $(0,3,6,12,24$, and $48 \mathrm{~h})$ indicating there was no change in the cell wall. This result was expected as these compounds have a bacteriostatic mode of action and bacteriostatic antibiotics act by inhibiting bacterial protein synthesis [36].

\subsection{Adherence Assessment}

Subdoses (1/2 MIC) of 7-epi or 7-epi-Cu did not induce adhesion of S. agalactiae and S. uberis isolated from bovine mastitis.

The adhesion induction have clinical relevance because successful establishment of an infection by bacterial pathogens requires adherence to host cells and colonization of tissues [37]. Evidence suggests that antibiotics at sub-therapeutic doses stimulate bacteria to alter their metabolism and express virulence factors for adhesion and invasion [38-40]. These concentrations are present at the beginning and end of dosing regimens and during low dose treatments [41,42], as well as when antibiotics are used at concentrations below dose therapy (ppm) as additives in animal feed in order to promote growth and control diseases [43].

Staphylococcus aureus subjected to sub-doses of florfenicol and ciprofloxacin exhibited increased adherence to host cells. In Escherichia coli and Pseudomonas aeruginosa, aminoglycosides also increased adherence to host tissue [44].

Adhesion and internalization of $S$. uberis in mammary epithelial cells are important early events in the establishment of mastitis in cows [45]. Adhesion of $S$. agalactiae to host cells is a relevant stage of colonization $[46,47]$.

Adhesion is the first step in the installation of an infection and also the first step in biofilm formation. Bacterial adhesion to the surface can be divided into different phases: primary and reversible adhesion, secondary and reversible adhesion, and biofilm formation [48]. A biofilm is defined as a cluster of cells enclosed in a self-produced matrix [49]. Due to the ability of biofilms to resist penetration by antimicrobials, biomedical research is focusing on the ability of bacteria to form biofilms. In clinical veterinary research, the characteristics of and therapeutic results in the treatment of mastitis suggest that biofilms are formed by mastitis-causing pathogens [50].

The compounds tested here did not induce adhesion. This result is clinically relevant.

\subsection{Cytotoxic Effect}

A comparison of the values obtained from treated cells and controls in a MTT (3-(4,5-dimethylthiazol2-yl)-2,5-diphenyltetrazolium bromide) test showed no statistical difference in the formation of formazan by mitochondrial dehydrogenases, indicating that the tested compounds were not cytotoxic. These values were similar even when using concentrations at $7 \times$ MIC (Figure 10).

Despite statistical results, microscopic analysis of cell cultures exposed to 7-epi and 7-epi-Cu showed that both compounds are not cytotoxic at their MIC in MAC-T cells. At this concentration there was no observed change in cell morphology. However, at $7 \times$ MIC the treated cells were more rounded than the control cells and had vacuolated cytoplasm. Moreover, in this treatment there was detachment and cell lysis. Therefore, further tests are needed to define the highest concentration at which the compounds are not toxic to this cell line. 


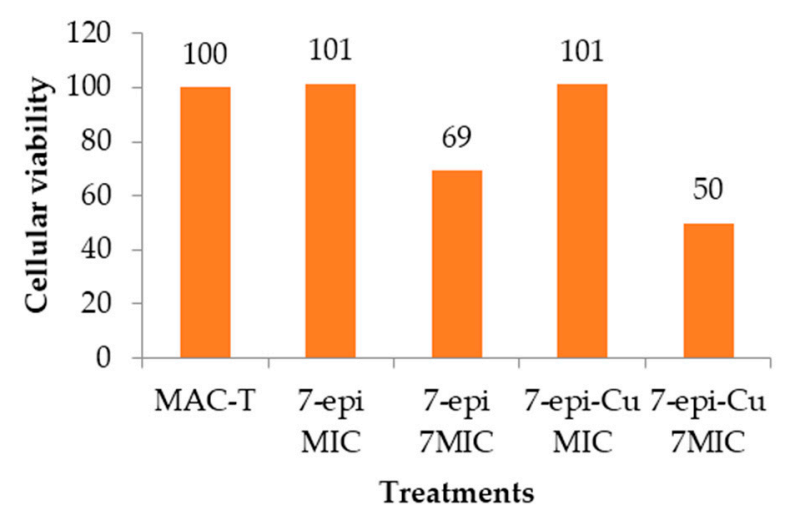

Figure 10. MAC-T viability by MTT assay. MAC-T cells were treated with 7-epiclusianone (7-epi) and 7-epiclusianone-copper (7-epi-Cu) for $24 \mathrm{~h}$ at the minimum inhibitory concentration (MIC) and seven times this concentration $(7 \times \mathrm{MIC})$. The results were presented as cell viability in relation to the control (MAC-T), which was considered $100 \%$.

\section{Materials and Methods}

\subsection{Chemistry, Strains, and Culture Medium}

The complex of 7-epi with $\mathrm{Cu}^{2}+$ [3-benzoyl-4-hydroxy-6,6-dimethyl-1,5,7-tris(e-methyl-2-butenyl) bicycle[3.3.1]non-3-ene-2,9-dione-copper], with the molecular formula $\mathrm{C}_{66} \mathrm{H}_{82} \mathrm{CuO}_{8}$, is a new compound obtained from 7-epi. The compound 7-epi was isolated and characterized by $\mathrm{X}$-ray diffraction by Santos [6,51]. For the synthesis of 7-epi-Cu, 7-epi was weighed out, dissolved in ethanol, and added to potassium bicarbonate. The potassium bicarbonate ionized the benzophenone, which is a weak acid $(\mathrm{pKa}=3.756)[52]$, and increased complexation. The metal ion $\mathrm{Cu}^{2+}$ was added to ionize the chelator molecule and there was a large excess of metal relative to benzophenone, which shifted the equilibrium toward complex formation. It was extremely important that there was no water in the solution because potassium bicarbonate reacts directly with water in a process called "hydrolysis" to produce hydroxyls that compete with the benzophenone for complexation with the metal. Subsequently the solution was filtered to remove excess potassium bicarbonate and chloroform was added. At that time, the ethanol was extracted with water in a funnel. At this stage, water did not affect the complexation because there was no excess of sodium bicarbonate to hydrolyze it, and also the whole complex was transferred to the chloroform phase. The chloroform phase was evaporated to obtain the complex. The compound 7-epi-Cu (Figure 2) was characterized by elemental analysis (CHN), atomic absorption, TG, IR, NMR, UV-VIS spectroscopy and $[\alpha]_{D}$.

At the time of utilization, compounds were solubilized in dimethyl sulfoxide (DMSO) and phosphate-buffered saline (PBS) pH 7.6 and heated in a water bath (Modelo 102, Fanem, São Paulo, SP, Brazil) at $60{ }^{\circ} \mathrm{C}$ (a temperature at which the compounds do not deteriorate).

Two Streptococcus agalactiae strains, SA3930 and SA4038, and two Streptococcus uberis strains, SU959 and SU3580, at $10^{5}$ colony forming units (CFU) $\mathrm{mL}^{-1}$ in tryptic soy broth (TSB) were used. These strains belong to Empresa Brasileira de Pesquisa Agropecuária-Gado de Leite, and they were obtained from the milk of cows with mastitis in Zona da Mata Mineira, an important milk-producing region in Brazil.

\subsubsection{Instrumentation General Methods}

UV-Visible spectra were determined on a spectrophotometer (UV-1601 PC, Himadzu, Tokyo, Japan). Infrared spectra were recorded on a Perkin Elmer Paragon 1000 FTIR spectrophotometer (Perkin Elmer, Waltham, MA, USA) (range from 400 to $4000 \mathrm{~cm}^{-1}$ ); ${ }^{1} \mathrm{H}$ - and ${ }^{13} \mathrm{C}-\mathrm{NMR}$ spectra were run on a Varian Mercury ( $300 \mathrm{MHz}$ ) system (Varian, Palo Alto, CA, USA). The proton chemical shifts are reported relative to the signal of the residual chloroform in $\delta=7.27 \mathrm{ppm}$ and TMS (tetramethylsilane) at $\delta=0.00 \mathrm{ppm}$. 
The ${ }^{13} \mathrm{C}$ chemical shifts are reported using the signal in $\delta=77 \mathrm{ppm}$ from $\mathrm{CDCl}_{3}$ as a reference. Optical rotations were measured on a Perkin-Elmer-241 spectrophotometer (Perkin Elmer, Waltham, MA, USA); Elemental analysis: PE 2400 Series II CHNS/O Analyzer Perkin Elmer Instruments (Perkin Elmer, Waltham, MA, USA). The chromatography were performed by silica gel HPTLC (high-performance thin layer chromatography) plates (Sigma-Aldrich ${ }^{\circledR}$, Newark, DE, USA), eluted with hexane:ethyl-acetate $(70: 30 v / v)$ to obtain the Rf (retention factor).

\subsubsection{7-Epiclusianone-Cu Physical Data}

Green amorphous powder $\left(\mathrm{CHCl}_{3}\right) ;[\alpha]_{\mathrm{D}}^{25}-70.1^{\circ}\left(c\right.$ 1.0, $\left.\mathrm{CHCl}_{3}\right) ; R_{\mathrm{f}} 0.30$ (hexane:ethyl-acetate $(85: 15 v / v)$ in silica gel HPTLC); UV-Vis (MeOH, $\left.0.4 \mathrm{mmol} \mathrm{L}^{-1}\right) \lambda_{\max }$ (Abs) 228 (0.82), 256 (1.20), 315 (0.84), 667 (0.06) nm; IR (film) $v_{\max }$ 3062, 2966, 2913, 2856, 1725, 1656, 1533, $1387 \mathrm{~cm}^{-1}$; Elementary analysis: experimental, $\mathrm{C}(75.66 \%), \mathrm{H}(7.60 \%), \mathrm{Cu}(6.19 \%)$; calculated for $\mathrm{C}_{66} \mathrm{H}_{82} \mathrm{CuO}_{8}, \mathrm{C}(74.30 \%)$, $\mathrm{H}(7.75 \%), \mathrm{Cu}(5.96 \%) ;{ }^{1} \mathrm{H}-\mathrm{NMR}\left(300 \mathrm{MHz} \mathrm{CDCl}_{3}\right) \delta(\mathrm{ppm}): 0.6-1.6\left(8 \mathrm{~s}\right.$, relative to $8 \mathrm{CH}_{3}(\delta), 1.5-3.34$ $\left(\mathrm{m}\right.$, relative to $\left.4 \mathrm{CH}_{2}\right), 1.0(\mathrm{~m}$, relative to $-\mathrm{CH}), 4.5-5.5(\mathrm{~m}$, relative to $3 \mathrm{C}=\mathrm{C}-\mathrm{H})(\delta), 6.5-7.65$ ( $\mathrm{m}$, relative to $\mathrm{C}=\mathrm{C}-\mathrm{H}_{\text {aromatic) }}{ }^{13} \mathrm{C}-\mathrm{NMR}\left(75 \mathrm{MHz}_{\mathrm{CDCl}}\right) \delta$ (ppm): 208.1, 197.5, 196.7, 193.6, 136.7, 134.8, 134.3, 134.2, $133.7,128.6,127.7,124.0,120.0,119.7,115.87,68.6,63.1,58.4,48.8,46.6,40.3,30.5,29.6,28.9,26.9,26.1$, $25.9,25.8,22.6,18.0,17.7$.

\subsection{Minimum Inhibitory Concentration (MIC)}

The four bacterial strains were submitted to minimum inhibitory concentration (MIC) tests by the microdilution broth as recommended by the Clinical and Laboratory Standards Institute [53]. Briefly, after compounds were solubilized two-fold serial dilutions were made in PBS (pH 7.6). Each well of a 96-well microtiter plate received $100 \mu \mathrm{L}$ of bacterial culture and $100 \mu \mathrm{L}$ of compound solution at the desired concentration (1-125 $\mu \mathrm{g} \mathrm{mL}^{-1}$ for 7-epi and 0.5-62.5 $\mu \mathrm{g} \mathrm{mL} \mathrm{m}^{-1}$ for 7-epi-Cu). A growth control was composed of $100 \mu \mathrm{L}$ of bacterial culture with $100 \mu \mathrm{L}$ of TSB, and the sterility control was $200 \mu \mathrm{L}$ of TSB. Experiments were carried out in triplicate and repeated three times. A DMSO control was conducted previously and was shown to affect microbial growth at a concentration of $125 \mu \mathrm{g} \mathrm{mL}^{-1}$.

After inoculation, microtiter plates were incubated at $37^{\circ} \mathrm{C}$ for $24 \mathrm{~h}$ before reading the results with a spectrophotometer (Titertek multiskan ${ }^{\circledR}$ Plus-MKII, Flow Laboratories, Inc., McLean, VA, USA) at $550 \mathrm{~nm}$. The MIC was designated as the lowest concentration capable of inhibiting bacterial growth, which was verified by comparing culture turbidity to the controls.

\subsection{Minimum Bactericidal Concentration (MBC)}

MBC was determined according to Dzotam [54]. After determining the MIC, $50 \mu \mathrm{L}$ were taken from each well of the microtiter plate where no bacterial growth was observed and transferred to a new plate with $150 \mu \mathrm{L}$ of TSB in each well. The plate was incubated at $37^{\circ} \mathrm{C}$ for $24 \mathrm{~h}$. After incubation, the plate was read with a spectrophotometer (Titertek multiskan ${ }^{\circledR}$ Plus-MKII, Flow Laboratories, Inc., McLean, VA, USA) (550 nm).

MBC was designated as the lowest concentration where there was no bacterial growth, as verified by comparing the turbidity of the culture to controls. The experiment was performed in triplicate and repeated three times.

\subsection{Time Kill Curve}

Time kill curves for SA4038 and SU3580 were determined according to Li [55], with modifications. Cultures in broth were incubated with the two compounds at their MIC and MBC. At predetermined times $(0,4,8,12$, and $24 \mathrm{~h})$ a $50 \mu \mathrm{L}$ aliquot was removed and diluted in ten-fold serial dilutions in $0.9 \%$ $(w / v)$ autoclaved saline. Fifty microliters of each dilution was spread onto brain heart infusion agar in duplicate. A growth control was carried out in the absence of the test compounds. After incubating 
plates for $24 \mathrm{~h}$ at $37^{\circ} \mathrm{C}, \mathrm{CFUs}$ on plates with 25-300 colonies were counted. At the end, the number of counts were fit with a logarithmic function in Microsoft Excel ${ }^{\circledR} 2010$ software.

\subsection{Protein Leakage Assay}

Quantification of protein leakage from SA4038 and SU3580 exposed to 7-epi and 7-epi-Cu was determined according to Oyedemi et al. [56] and Bhande et al. [57], with modifications. The protein content in the supernatant of bacterial suspensions treated with the two compounds at their MIC collected at $0,3,6,12,24$, and $48 \mathrm{~h}$ was determined by centrifugation at $3000 \times \mathrm{g}$ for $30 \mathrm{~min}$ at $4{ }^{\circ} \mathrm{C}$. The protein concentration was determined by the Bradford method [58] using bovine serum albumin to generate a standard curve. Controls were bacterial solutions in the absence of compound and compounds alone. Results were measured by spectrophotometry (Titertek multiskan ${ }^{\circledR}$ Plus-MKII, Flow Laboratories, Inc., McLean, VA, USA) (550 nm).

\subsection{Adherence Assessment}

To evaluate if the tested compounds induced bacterial adhesion, we tested the sub-inhibitory concentration equal to $1 / 2$ MIC [41]. Each well of a microtiter plate received $100 \mu \mathrm{L}$ of bacterial culture and $100 \mu \mathrm{L}$ of compound solution. The positive control consisted of $100 \mu \mathrm{L}$ of culture with $100 \mu \mathrm{L}$ of $0.9 \%(w / v)$ saline solution and the negative control was just TSB. Plates were incubated at $37^{\circ} \mathrm{C}$ for $24 \mathrm{~h}$, washed three times with distilled water and dried at room temperature. Subsequently, they were incubated with $250 \mu \mathrm{L}$ of methanol for $15 \mathrm{~min}$. After drying, wells were stained with a $2 \%$ crystal violet solution for $10 \mathrm{~min}$, washed with autoclaved distilled water and dried at room temperature. Finally, $250 \mu \mathrm{L}$ of $33 \%$ glacial acetic acid was added, and the results were read with a spectrophotometer (Titertek multiskan ${ }^{\circledR}$ Plus-MKII, Flow Laboratories, Inc., McLean, VA, USA) at $550 \mathrm{~nm}$.

The induction of adhesion was measured by absorbance at $550 \mathrm{~nm}$, and the absorbance of the treated wells was compared to the controls. All procedures were performed in triplicate and repeated three times.

\subsection{Cytotoxic Effect in MAC-T}

The MAC-T cells were kindly provided by Yung-Fu Chang at the Medical College of Veterinary Medicine, Cornell University, Ithaca, NY. MAC-T cells were grown in flat-bottom 96-well culture plates in Dulbecco's Modified Eagle Medium supplemented with $10 \%$ fetal bovine serum, penicillin $\left(100 \mu \mathrm{g} \mathrm{mL}^{-1}\right)$, and streptomycin $\left(100 \mu \mathrm{g} \mathrm{mL}^{-1}\right)$. Cells were incubated at $37^{\circ} \mathrm{C}$ with $5 \% \mathrm{CO}_{2}$ and $95 \% \mathrm{O}_{2}$ for $24 \mathrm{~h}$. Cell growth was visualized and monitored with an inverted microscope until they reached confluency $\left(3 \times 10^{5}\right.$ cells) [41].

The compounds were used at concentrations equivalent to their MIC and 7× MIC. Cytotoxicity was assessed using an MTT assay as described by Al-Sheddi et al. [59]. Briefly, MAC-T cells were exposed to the compounds for $24 \mathrm{~h}$. Then $10 \mu \mathrm{L}$ of MTT (stock solution $5 \mathrm{mg} \mathrm{mL}^{-1}$ in PBS, pH 7.6) were added in $100 \mu \mathrm{L}$ of media per well and incubated for $4 \mathrm{~h}$. The supernatant was discarded and $200 \mu \mathrm{L}$ of DMSO was added to each well to dissolve the crystals that had formed. The plate was gently stirred. The color that developed was read with a spectrophotometer (Titertek multiskan ${ }^{\circledR}$ Plus-MKII, Flow Laboratories, Inc., McLean, VA, USA) at $550 \mathrm{~nm}$. Cells not exposed to the compound served as a control. The experiment was carried out in quadruplicate.

\subsection{Statistical Analysis}

The averages obtained from the MTT test, protein leakage assay, and adherence assessment were compared by an analysis of variance (ANOVA), followed by Tukey's method, using SASM-Agri software [60]. The significance level was 5\% $(p<0.05)$. 


\section{Conclusions}

The compounds 7-epi and 7-epi-Cu exhibited desirable antimicrobial characteristics and could potentially be used to treat bovine mastitis. Future work will focus on conducting clinical trials with these compounds. Although substantial differences were not observed between 7-epi and its new complex, 7-epi-Cu, the latter could still provide exciting results in other biological tests or with other microorganisms.

Acknowledgments: The authors thank to the financial support from Coordenação de Aperfeiçoamento de Pessoal de Nível Superior (Capes), Conselho Nacional de Desenvolvimento Científico e Tecnológico (CNPq) and Fundação de Amparo à Pesquisa de Minas Gerais (Fapemig). Maria Aparecida Scatamburlo Moreira is supported by CNPq.

Author Contributions: All authors conceived and designed the experiments; Mariana de Barros and Éderson D'Martin Costa performed the experiments; all authors analyzed the data; all authors contributed reagents/materials/analysis tools; Mariana de Barros, Éderson D'Martin Costa Marcelo Henrique dos Santos and Maria Aparecida Scatamburlo Moreira wrote the paper.

Conflicts of Interest: The authors declare no conflict of interest.

\section{References}

1. Maciel, M.A.M.; Pinto, A.C.; Veiga, V.F., Jr.; Grynberg, N.F.; Echevarria, A. Plantas medicinais: A necessidade de estudos multidisciplinares. Quim. Nova 2002, 25, 429-438. [CrossRef]

2. Sponchiado, G.; Adam, M.L.; Silva, C.D.; Soley, B.S.; Mello-Sampayo, C.; Cabrini, D.A.; Correr, C.J.; Otuki, M.F. Quantitative genotoxicity assays for analysis of medicinal plants: A systematic review. J. Ethnopharmacol. 2016, 178, 289-296. [CrossRef] [PubMed]

3. Dutra, R.C.; Campos, M.M.; Santos, A.R.S.; Calixto, J.B. Medicinal plants in Brazil: Pharmacological sudies, drug discovery, challenges and perspectives. Pharmacol. Res. 2016, 436, 1-25. [CrossRef] [PubMed]

4. Ionta, M.; Ferreira-Silva, G.A.; Niero, E.L.; Costa, É.D'M.; Martens, A.A.; Rosa, W.; Soares, M.G.; Machado-Santelli, G.M.; Lago, J.H.G.; Santos, M.H. 7-Epiclusianone, a Benzophenone Extracted from Garcinia brasiliensis (Clusiaceae), Induces Cell Cycle Arrest in G1/S Transition in A549 Cells. Molecules 2015, 20, 12804-12816. [CrossRef] [PubMed]

5. Carvalho-Silva, L.B.; Oliveira, M.V.; Gontijo, V.S.; Oliveira, W.F.; Derogis, P.B.M.C.; Stringheta, P.C.; Nagem, T.J.; Brigagão, M.R.P.L.; dos Santos, M.H. Antioxidant, cytotoxic and antimutagenic activities of 7-epi-clusianone obtained from pericarp of Garcinia brasiliensis. Food Res. Int. 2012, 48, 180-186. [CrossRef]

6. Santos, M.H.; Nagem, T.J.; Oliveira, T.T.; Braz-Filho, R. 7-Epiclusianona, a nova benzofenona tetraprenilada e outros constituintes químicos dos frutos de Rheedia gardneriana. Quim. Nova 1999, 22, 654-660. [CrossRef]

7. Alves, T.M.A.; Alves, R.O.; Romanha, A.J.; Santos, M.H.; Nagem, T.J.; Zani, C.L. Biological Activities of 7-Epiclusianone. J. Nat. Prod. 1999, 62, 369-371. [CrossRef] [PubMed]

8. Cruz, A.J.; Lemos, V.S.; dos Santos, M.H.; Nagem, T.J.; Cortes, S.F. Vascular effects of 7-epiclusianone, a prenylated benzophenone from Rheedia gardneriana, on the rat aorta. Phytomedicine 2006, 13, 442-445. [CrossRef] [PubMed]

9. Neves, J.S.; Coelho, L.P.; Cordeiro, R.S.B.; Veloso, M.P.; Silva, P.M.R.; Santos, M.H.; Martins, M.A. Antianaphylactic properties of 7-epiclusianone, a tetraprenylated benzophenone isolated from Garcinia brasiliensis. Planta Med. 2007, 73, 644-649. [CrossRef] [PubMed]

10. Piccinelli, A.L.; Cuesta-Rubio, O.; Chica, M.B.; Mahmood, N.; Pagano, B.; Pavone, M.; Barone, V.; Rastrelli, L. Structural revision of clusianone and 7-epi-clusianone and anti-HIV activity of polyisoprenylated benzophenones. Tetrahedron 2005, 61, 8206-8211. [CrossRef]

11. Santa-Cecília, F.V.; Freitas, L.A.S.; Vilela, F.C.; Veloso, C.C.; da Rocha, C.Q.; Moreira, M.E.C.; Dias, D.F.; Giusti-Paiva, A.; Santos, M.H. Antinociceptive and anti-inflammatory properties of 7-epiclusianone, a prenylated benzophenone from Garcinia brasiliensis. Eur. J. Pharmacol. 2011, 670, 280-285. [CrossRef] [PubMed]

12. Vieira, F.T.; Maia, J.R.S.; Vilela, M.J.; Ardisson, J.D.; Santos, M.H.; Oliveira, T.T.; Nagem, T.J. Spectroscopic Investigation of Organotin (IV) Derivatives of 7-Epiclusianone: A preliminary in vitro Antitumor Evaluation of the HN-5 Human Carcinoma Cell. Main Group Met. Chem. 2009, 32, 235-246. [CrossRef] 
13. Santi, E.; Facchin, G.; Faccio, R.; Barroso, R.P.; Costa-Filho, A.J.; Borthagaray, G.; Torre, M.H. Antimicrobial evaluation of new metallic complexes with xylitol active against $P$. aeruginosa and C. albicans: MIC determination, post-agent effect and Zn-uptake. J. Inorg. Biochem. 2016, 155, 67-75. [CrossRef] [PubMed]

14. Dizaj, S.M.; Lotfipour, F.; Barzegar-Jalali, M.; Zarritan, M.H.; Adibkia, K. Antimicrobial activity of the metals and metal oxide nanoparticles. Mater. Sci. Eng. C 2014, 44, 278-284. [CrossRef] [PubMed]

15. Nunes, J.H.B.; de Paiva, R.E.F.; Cuin, A.; Ferreira, A.M.C.; Lustri, W.R.; Corbi, P.P. Synthesis, spectroscopic characterization, crystallographic studies and antibacterial assays of new copper(II) complexes with sulfathiazole and nimesulide. J. Mol. Struct. 2016, 1112, 14-20. [CrossRef]

16. Silva, P.B.; Bonifácio, B.V.; Frem, R.C.G.; Godoy Netto, A.V.; Mauro, A.E.; Ferreira, A.M.C.; Lopes, E.O.; Raddi, M.S.G.; Bauab, T.M.; Pavan, F.R.; et al. Nanostructured Lipid System as a Strategy to Improve the in Vitro Antibacterial Activity of Copper(II) Complexes. Molecules 2015, 20, 761-772. [CrossRef] [PubMed]

17. Ingle, A.P.; Duran, N.; Rai, M. Bioactivity, mechanism of action, and cytotoxicity of copper-based nanoparticles: A review. Appl. Microbiol. Biotechnol. 2014, 98, 1001-1009. [CrossRef] [PubMed]

18. Hefnawy, A.E.; El-Khaiat, H.M. The Importance of Copper and the Effects of Its Deficiency and Toxicity in Animal Health. Int. J. Livest. Res. 2015, 5, 1. [CrossRef]

19. Humann-Ziehank, E. Selenium, copper and iron in veterinary medicine-From clinical implications to scientific models. J. Trace Elem. Med. Biol. 2016, 37, 96-103. [CrossRef] [PubMed]

20. Richards, V.P.; Lefébure, T.; Bitar, P.D.P.; Dogan, B.; Simpson, K.W.; Schukken, Y.H.; Stanhope, M.J. Genome Based Phylogeny and Comparative Genomic Analysis of Intra-Mammary Pathogenic Escherichia coli. PLoS ONE 2015, 10, 1-11. [CrossRef] [PubMed]

21. Petrovski, K.R.; Trajcev, M.; Buneski, G. A review of the factors affecting the costs of bovine mastitis. J. S. Afr. Vet. Assoc. 2006, 77, 52-60. [CrossRef] [PubMed]

22. Oliveira, J.M.B.; Vanderlei, D.R.; Moraes, W.S.; Brandespim, D.F.; Mota, R.A.; Oliveira, A.A.F.; Medeiros, E.S.; Pinheiro Júnior, J.W. Fatores de risco associados à mastite bovina na microrregião Garanhuns, Pernambuco. Pesqui. Vet. Bras. 2012, 32, 391-395. [CrossRef]

23. Altalhi, A.D.; Hassan, S.A. Bacterial quality of raw milk investigated by Escherichia coli and isolates analysis for specific virulence-gene markers. Food Control 2009, 20, 913-917. [CrossRef]

24. Carvalho, I.A.; Pietralonga, P.A.G.; Schwarz, D.G.G.; Faria, A.C.S.; Moreira, M.A.S. Short communication: Recovery of viable Mycobacterium avium subspecies paratuberculosis from retail pasteurized whole milk in Brazil. J. Dairy Sci. 2012, 95, 6946-6948. [CrossRef] [PubMed]

25. Hamadani, H.; Khan, A.A.; Banday, M.T.; Ashraf, I.; Handoo, N.; Bashir, A.; Hamadani, A. Bovine Mastitis-A Disease of Serious Concern for Dairy Farmers. Int. J. Livest. Res. 2013, 3, 42-55. [CrossRef]

26. Wang, W.; Song, Y.; Petrovski, K.; Eats, P.; Trott, D.J.; Wong, H.S.; Page, S.W.; Perry, J.; Garg, S. Development of intramammary delivery systems containing lasalocid for the treatment of bovine mastitis: Impact of solubility improvement on safety, efficacy, and milk distribution in dairy cattle. Drug Des. Dev. Ther. 2015, 9, 631-642.

27. Nani, J.P.; Raschia, M.A.; Carignano, H.; Poli, M.A.; Calvinho, L.F.; Amadio, A.F. Single nucleotide polymorphisms in candidate genes and their relation with somatic cell scores in Argentinean dairy cattle. J. Appl. Genet. 2015, 56, 505-513. [CrossRef] [PubMed]

28. Ríos, J.L.; Recio, M.C. Medicinal plants and antimicrobial activity. J. Ethnopharmacol. 2005, 100, 80-84. [CrossRef] [PubMed]

29. Cos, P.; Vlietinck, A.J.; Berghe, D.V.; Maes, L. Anti-infective potential of natural products: How to develop a stronger in vitro "proof-of-concept". J. Ethnopharmacol. 2006, 106, 290-302. [CrossRef] [PubMed]

30. Lemire, J.A.; Harrison, J.J.; Turner, R.J. Antimicrobial activity of metals: mechanisms, molecular targets and applications. Nat. Rev. Microbiol. 2013, 11, 371-384. [CrossRef] [PubMed]

31. Wernicki, A.; Puchalski, A.; Urban-Chmiel, R.; Dec, M.; Stegierska, D.; Dudzic, A.; Wójcik, A. Antimicrobial properties of gold, silver, copper and platinum against selected microorganisms isolated from cases of mastitis in cattle. Med. Weter. 2014, 70, 4.

32. Nielsen, E.I.; Viberg, A.; Löwdin, E.; Cars, O.; Karlsson, M.O.; Sandström, M. Semimechanistic Pharmacokinetic /Pharmacodynamic Model for Assessment of Activity of Antibacterial Agents from Time-Kill Curve Experiments. Antimicrob. Agents Chemother. 2007, 51, 128-136. [CrossRef] [PubMed]

33. Pankey, G.A.; Sabath, L.D. Clinical Relevance of Bacteriostatic versus Bactericidal Mechanisms of Action in the Treatment of Gram-Positive Bacterial Infections. Clin. Infect. Dis. 2004, 38, 864-870. [CrossRef] [PubMed] 
34. Nemeth, J.; Oesch, G.; Kuster, S.P. Bacteriostatic versus bactericidal antibiotics for patients with serious bacterial infections: Systematic review and meta-analysis. J. Antimicrob. Chemother. 2015, 70, 382-395. [CrossRef] [PubMed]

35. Diao, W.-R.; Hu, Q.-P.; Zhang, H.; Xu, J.-G. Chemical composition, antibacterial activity and mechanism of action of essential oil from seeds of fennel (Foeniculum vulgare Mill.). Food Control 2014, 35, 109-116. [CrossRef]

36. Brötz-Oesterhelt, H.; Brunner, N.A. How many modes of action should an antibiotic have? Curr. Opin. Pharmacol. 2008, 8, 564-573. [CrossRef] [PubMed]

37. Pizarro-Cerdá, J.; Cossart, P. Bacterial Adhesion and Entry into Host Cells. Cell 2006, 124, 715-727. [CrossRef] [PubMed]

38. Costa, J.C.M.; Espechit, I.F.; Pieri, F.A; Benjamin, L.A.; Moreira, M.A.S. Increased production of biofilms by Escherichia coli in the presence of enrofloxacin. Vet. Microbiol. 2012, 160, 488-490. [CrossRef] [PubMed]

39. Hoffman, L.R.; D'Argenio, D.A.; MacCoss, M.J.; Zhang, Z.; Jones, R.A.; Miller, S.I. Aminoglycoside antibiotics induce bacterial biofilm formation. Nature 2005, 436, 1171-1175. [CrossRef] [PubMed]

40. Bradley, A.J.; Green, M.J. Factors affecting cure when treating bovine clinical mastitis with cephalosporin -based intramammary preparations. J. Dairy Sci. 2009, 92, 1941-1953. [CrossRef] [PubMed]

41. Silva, V.O.; Soares, L.O.; Silva Júnior, A.; Mantovani, H.C.; Chang, Y.-F.; Moreira, M.A.S. Biofilm Formation on Biotic and Abiotic Surfaces in the Presence of Antimicrobials by Escherichia coli Isolates from Cases of Bovine Mastitis. Appl. Environ. Microbiol. 2014, 80, 6136-6145. [PubMed]

42. Odenholt, I. Pharmacodynamic effects of subinhibitory antibiotic concentrations. Int. J. Antimicrob. Agents 2001, 17, 1-8. [PubMed]

43. Wallinga, D.; Burch, D.G.S. Does adding routine antibiotics to animal feed pose a serious risk to human health? BMJ 2013, 347, 9-11.

44. Andersson, D.I.; Hughes, D. Microbiological effects of sublethal levels of antibiotics. Nat. Rev. Microbiol. 2014, 12, 465-478. [PubMed]

45. Almeida, R.A.; Dego, O.K.; Headrick, S.I.; Lewis, M.J.; Oliver, S.P. Role of Streptococcus uberis adhesion molecule in the pathogenesis of Streptococcus uberis mastitis. Vet. Microbiol. 2015, 179, 332-335. [PubMed]

46. Chuzeville, S.; Dramsi, S.; Madec, J.-Y.; Haenni, M.; Payot, S. Antigen I/II encoded by integrative and conjugative elements of Streptococcus agalactiae and role in biofilm formation. Microb. Pathog. 2015, 88, 1-9. [PubMed]

47. Nobbs, A.H.; Jenkinson, H.F.; Everett, D.B. Generic determinants of Streptococcus colonization and infection. Infect. Genet. Evol. 2015, 33, 361-370. [PubMed]

48. Dunne, W.M., Jr. Bacterial Adhesion: Seen Any Good Biofilms Lately? Clin. Microbiol. Rev. 2002, 15, 155-166. [PubMed]

49. Gomes, F.; Henriques, M. Control of Bovine Mastitis: Old and Recent Therapeutic Approaches. Curr. Microbiol. 2016, 72, 377-382. [PubMed]

50. Melchior, M.B.; Vaarkamp, H.; Fink-Gremmels, J. Biofilms: A role in recurrent mastitis infections? Vet. J. 2006, 171, 398-407. [PubMed]

51. Santos, M.H.; Speziali, N.L.; Nagem, T.J.; Oliveira, T.T. Epiclusianone: A New Natural Product Derivative of Bicyclo[3.3.1]nonane-2,4,9-trione. Acta Crystallogr. Sect. C Cryst. Struct. Commun. 1998, 54, 1990-1992. [CrossRef]

52. Costa, É.D’M.; Lemes, N.H.T.; Santos, M.H.; Braga, J.P. Uso de redes neurais recorrentes na determinação das constantes de acidez para a 7-epiclusianona em misturas etanol-água. Quim. Nova 2012, 35, 91-96. [CrossRef]

53. CLSI. Methods for Dilution Antimicrobial Susceptibility Tests for Bacteria that Grow Aerobically: Approved Standard, 9th ed.; Clinical and Laboratorial Standards Institute: Wayne, PA, USA, 2012; Volume 32.

54. Dzotam, J.K.; Touani, F.K.; Kuete, V. Antibacterial and antibiotic-modifying activities of three food plants (Xanthosoma mafaffa Lam., Moringa oleifera (L.) Schott and Passiflora edulis Sims) against multidrug-resistant (MDR) Gram-negative bacteria. BMC Complement. Altern. Med. 2016, 16, 9. [CrossRef] [PubMed]

55. Li, L.; Shi, C.; Yin, Z.; Jia, R.; Peng, L.; Kang, S.; Li, Z. Antibacterial activity of $\alpha$-terpineol may induce morphostructural alterations in Escherichia coli. Braz. J. Microbiol. 2014, 45, 1409-1413. [CrossRef] [PubMed]

56. Oyedemi, S.O.; Okoh, A.I.; Mabinya, L.V.; Pirochenva, G.; Afolayan, A.J. The proposed mechanism of bactericidal action of eugenol, $\alpha$-terpineol and $\gamma$-terpinene against Listeria monocytogenes, Streptococcus pyogenes, Proteus vulgaris and Escherichia coli. Afr. J. Biotechnol. 2009, 8, 1280-1286. 
57. Bhande, R.M.; Khobragade, C.N.; Mane, R.S.; Bhande, S. Enhanced synergism of antibiotics with zinc oxide nanoparticles against extended spectrum $\beta$-lactamase producers implicated in urinary tract infections. J. Nanoparticle Res. 2013, 15, 1-13. [CrossRef]

58. Bradford, M.M. A rapid and sensitive method for the quantitation of microgram quantities of protein utilizing the principle of protein-dye binding. Anal. Biochem. 1976, 72, 248-254. [CrossRef]

59. Al-Sheddi, E.S.; Farshori, N.N.; Al-Oqail, M.M.; Musarrat, J.; Al-Khedhairy, A.A.; Siddiqui, M. Protective effect of Lepidium sativum seed extract against hydrogen peroxide-induced cytotoxicity and oxidative stress in human liver cells (HepG2). Pharm. Biol. 2015, 54, 314-321. [CrossRef] [PubMed]

60. Canteri, M.G.; Althaus, R.A.; Virgens Filho, J.S.; Giglioti, E.A.; Godoy, C.V. SASM-Agri: Sistema para análise e separação de médias em experimentos agrícolas pelos métodos Scoft-Knott, Tukey e Duncan. Rev. Bras. Agrocomputação 2001, 1, 18-24.

Sample Availability: Samples of the compounds 7-epiclusianone and 7-epiclusianone-copper are available from the authors.

(C) 2017 by the authors. Licensee MDPI, Basel, Switzerland. This article is an open access article distributed under the terms and conditions of the Creative Commons Attribution (CC BY) license (http://creativecommons.org/licenses/by/4.0/). 